\title{
More Accurate, But No Less Polarized: Comparing the Factual Beliefs of Government Officials and the Public - CORRIGENDUM
}

Nathan Lee, Brendan Nyhan, Jason Reifler and D. J. Flynn

(First published online 11 February 2021)

https://doi.org/10.1017/S000712342000037X Published by Cambridge University Press, 24 November 2020.

Keywords: belief polarization; misperceptions; elite opinion; corrigendum

The authors apologize that the two images in the article were switched due to a production error. The image that appears in Figure 1 should appear in Figure 2 and vice versa.

\section{Reference}

Lee N, Nyhan B, Reifler J and Flynn DJ (2020) More Accurate, But No Less Polarized: Comparing the Factual Beliefs of Government Officials and the Public. British Journal of Political Science Published by Cambridge University Press, 24 November 2020. doi:10.1017/ S000712342000037X.

Cite this article: Lee N, Nyhan B, Reifler J, Flynn DJ (2021). More Accurate, But No Less Polarized: Comparing the Factual Beliefs of Government Officials and the Public - CORRIGENDUM. British Journal of Political Science 51, 1323. https:// doi.org/10.1017/S0007123420000903

(c) The Author(s), 2021. Published by Cambridge University Press. 